\title{
Proza drugiego pokolenia po Zagładzie: inne sposoby pamiętania*
}

W artykule Ocalali, pamięć i twórczość artystyczna Aharon Appelfeld odnosi się do literatury o Zagładzie jako do kierunku, który „był i jest uważany za działalność podejrzaną [...]. Działalność twórcza dozwolona jest we wszystkich dziedzinach poza tą jedną"1. Literatura o Holokauście istotnie musiała przejść długą drogę od znanego postulatu Adorna, który odrzucał pisanie poezji po Auschwitz, aż po akceptację tego zjawiska. O szczególnej pozycji literatury o Zagładzie przesądził fakt, że Szoa stanowiła z jednej strony wydarzenie historyczne, z drugiej - osobistą traumę tych, którzy przeżyli, oraz posttraumę, która spadła na ich potomków. Literatura zagładowa powstaje (i jest czytana) pod wpływem historycznego przywiązania do faktów i wydarzeń, a także osobistych (biograficznych) doświadczeń. Konteksty te zwiększają wagę wyborów artystycznych dokonywanych przez autorów i autorki, odnoszących się również do poetyki, które same w sobie stanowią rodzaj reakcji i świadectwa wobec historycznego wydarzenia, traumy i sposobu, w jaki nadal wywiera ona wpływ na teraźniejszość - rozumianą indywidualnie i zbiorowo ${ }^{2}$.

Centralna w tym kontekście jest kategoria cierpienia, jak przekonywał później Adorno, wygłaszając fundamentalne zdanie: „Cierpienie musi zostać wypowiedziane, dlatego twierdzenie, że po Auschwitz nie można już pisać poezji, mogło

* Za zgodę na publikację tekstu dziękujemy wydawnictwu Ha-Kibuc ha-Meuchad, wydawcy tomu Ha-Szoa: sza’at chinuch (red. S. Gewa. Tel Awiw 2017), w którym ukazał się hebrajski pierwodruk artykułu.

${ }^{1}$ A. Appelfeld: Ha-Nicolim, ha-zikaron we-ha-jecira ha-omanutit. „Biszwil ha-Zikaron” 1997, 24, s. 6.

${ }^{2}$ Kwestia relacji między literaturą a historią nie jest rzecz jasna wyjątkowa dla literatury o Zagładzie, jakkolwiek w kontekście Szoa mają one być może jeszcze bardziej złożony charakter. Tak czy inaczej, mowa o temacie szeroko opisanym, na który nie ma dość miejsca w tym artykule. Więcej na ten temat zob. M. BrIKner: Sifrut we-historia: He'arot ktanot le-nose gadol. W: Sifrut we-historia. Red. R. Cohen, W. MaAli. Jeruszalajim 1997, s. 33-43. 
być błędem”. W praktyce, pisał Adorno, „tylko dzięki sztuce cierpienie może znaleźć ulgę, sztuka go nie zdradzi. Najważniejsi artyści naszych czasów dali temu dowód"3. Blisko siedem dekad po wypowiedzeniu tych słów działalność twórcza jest ważnym mostem łączącym nas z pozostałymi katastrofą i pamięcią. Twórczość artystyczna, stanowiąc istotne źródło dla edukacji o Zagładzie, każe zmierzyć się z wydarzeniem ekstremalnym, z jego wpływem na tożsamość żydowską i społeczeństwo izraelskie oraz - w szczególności - z pytaniami aksjologicznymi i etycznymi.

Istnieje ogólna zgoda co do tego, że edukacja o Holokauście powinna mieć charakter interdyscyplinarny i obejmować tak wiele obszarów, jak to możliwe. Model taki szczegółowo omówiono na stronie Międzynarodowej Szkoły Edukacji o Zagładzie działającej przy Jad Waszem:

Nauczanie historii jest bardzo istotne dla zrozumienia tła, poznania faktów i przekazywania wiedzy, lecz nie wystarcza. Aby zmierzyć się ze wspomnianymi wyżej trudnościami, należy poszerzyć nauczanie o Zagładzie, szukając dróg, które prowadziłyby do niego z różnych obszarów - literatury, sztuki, filozofii itd. Istnieje wiele punktów stycznych między tematem Szoa a tymi dziedzinami - jak powiedział profesor Gerszon Szaked: „Siłą sztuki jest zazwyczaj wielość znaczeń, możliwość widzenia ludzkiej natury we wszystkich jej odcieniach" (z wykładu wygłoszonego w Jad Waszem w listopadzie 1995 roku, podczas ceremonii przyznania Idzie Fink nagrody Buchmana). Podejście do edukacji o Zagładzie z troską z kilku różnych stron podniesie kompetencje edukatorów w sposób najbardziej pogłębiony i kompleksowy".

Literatura Szoa, z jednej strony nosząca znamiona historycznego i osobistego świadectwa, z drugiej będąca artystyczną formą pisarstwa, stanowi istotną perspektywę edukacyjną z uwagi na swój „międzyobszarowy” charakter. Twórczość literacka w ogóle, w szczególności zaś ta dotykająca tematu Zagłady, jest rodzajem reakcji i świadectwa. Historyczne osadzenie literatury zagładowej wzmacnia dokumentalny wymiar pisarstwa, nawet gdy fabuła pozostaje fikcyjna. „Getto jest gettem, obóz koncentracyjny - obozem koncentracyjnym. To nie są przestrzenie literackie" - twierdzi Ben Ami Fajngold 5 . Edukacja o Holokauście zmaga się z szerokim znaczeniem terminów "getto” i „obóz koncentracyjny”, zarówno na poziomie faktów, jak i w sensie etycznym oraz aksjologicznym.

Twórczość literacka ocalałych, zarówno pisana w czasach Zagłady, jak i późniejsza, była i jest ważnym świadectwem wydarzeń i sytuacji, które Szoa

${ }^{3}$ Ze strony Jad Waszem Chinuch we-Hora'a Metukszewet: yadvashem.org/yv/he.

${ }^{4}$ L. Lachmanowic: Hora'at ha-Szoa be-emca'ut ha-sifrut: ma'arach szi'ur. Chinuch we-Hora'a Metukszewet - Jad wa-Szem. Ze strony Szkoły Edukacji o Zagładzie Jad Waszem: yad vashem.org/yv/he/education/newsletter/28/literature.asp [data dostępu: 27.02.2018].

${ }^{5}$ B.A. FAjngold: Hora'at sifrut ha-Szo'a - be'ajot ha-jesod. „Alon la-More le-Sifrut” 1992, 12 , s. 6 . 
narzuciła swoim ofiarom. Literatura ta balansuje między świadectwem a fikcją. Ocalali chcieli za jej pośrednictwem, jak wyraził to Aharon Appelfeld, oswoić grozę wydarzeń i ocalić pamięć o nich ${ }^{6}$. W mowie wygłoszonej podczas Wieczoru Pamięci o Zagładzie w Muzeum Jad Waszem w roku 1997 Appelfeld stwierdził, że „nie wolno pozostawić Zagłady na poziomie dużych liczb i uogólnień. Świadkowie i historycy położyli fundamenty i krokwie, teraz zaś przyszedł czas na działalność twórczą" . Gerszon Szaked powiedział natomiast w cytowanym już wykładzie, że „wielkość pisarzy pokolenia ocalałych tkwi w zrozumieniu, że niemożliwe jest mierzenie się z rzeczywistością Zagłady w perspektywie panoramicznej. Należało robić to stopniowo, przy użyciu małych porcji szczegółów reprezentujących całość"s. Świadectwo autentyczności literatury o Zagładzie daje też sama Ida Fink:

Najważniejsze w pisaniu na ten temat są dla mnie prawda i autentyczność. Wszystko, co napisałam, zawiera w sobie pierwiastek autentyczności. Literackie przetworzenie opiera się na fikcji, ale fikcję rozumiem tu jako dystans. To atmosfera, krajobraz, nie tylko geograficzny, ale też wewnętrzny, psychologiczny... Granica jest tu bardzo rozmyta i trudno do końca ustalić, którędy przebiega9 .

W niniejszym artykule pragnę przyjrzeć się wyjątkowemu wkładowi literatury drugiego (i trzeciego) pokolenia w Izraelu w korpus twórczości towarzyszącej edukacji o Zagładzie. Literatura ta, którą zaczęto wydawać w Izraelu w połowie lat 80. XX wieku, ukazuje się także dziś i wnosi do dyskursu o Szoa w ogóle, a do edukacji o niej w szczególności, perspektywę kolejnych wychowanych w cieniu traumy pokoleń. Również ich głos jest autentyczny i w naturalny sposób, jak twierdzi Esti G. Chajim, pisarka drugiego pokolenia, stanie się on głosem dającym świadectwo i podtrzymującym pamięć:

Niebawem, gdy zabraknie pierwszego pokolenia, my, drugie pokolenie, przejmiemy sztandar pamięci i staniemy się grupą najautentyczniej zaświadczającą o tych okropnościach. Będziemy opowiadać o rodzicach. O naszej matce, na której obolałym łonie wzrastaliśmy, karmieni jej bólem. O naszym ojcu, który wychował nas, nowe pisklęta, wśród popiołów własnego życia. Chcąc nie chcąc, odziedziczymy ich przeszłośćc ${ }^{10}$.

${ }^{6}$ Por. M. Stranin: Ha-Omanut hi tris bi-fnej ha-banalijut. Wywiad z Aharonem AppelFELDEM. „Zika - Ha-Iton ha-Mekuwan le-Hora'at ha-Szo'a”, gilion merc. Dostępne w Internecie: http://www.yadvashem.org/he/articles/interviews/aharon-appelfeld.html [data dostępu: 27.02.2018].

7 Cyt. za: L. Lachmanowic: Hora'at ha-Szoa be-emca'ut ha-sifrut...

${ }^{8}$ Cyt. za: tamże.

9 D. Blatman: Anachnu asirim szel ha-zikaron we-szel ha-zman. Rozmowa z Idą Fink. „Biszwil ha-Zikaron" 1996, 11, s. 8.

${ }^{10}$ E.G. Chajim: Anszej Pinot. Or Jehuda 2013, s. 11. 
Jak głosi pisarka, drugie pokolenie wchodzi w rolę strażników pamięci, przejmuje „sztandar pamięci” wraz z troską o to, aby głos przeszłości pozostał słyszalny. W niniejszym artykule zamierzam wykazać, że pamięć, której literatura drugiego pokolenia chce dać wyraz, jest kolejnym głosem $\mathrm{w}$,,izraelskim chórze pamięci", głosem, który nie zawsze wpisuje się w dominujący dyskurs pamięciowy. Literatura drugiego pokolenia stwarza obszar spotkania, łączy autentyczną pamięć rodziców z izraelską rzeczywistością tu i teraz w sposób różny od tego, w jaki robi to znany dyskurs publiczny. Co więcej, jak się zdaje, literacka twórczość drugiego pokolenia dystansuje się od rozwijanych przez ten dyskurs związków między Zagładą i pamięcią o niej a areną polityczną. Drugie pokolenie zawiera w swoich tekstach krytykę, wyrażaną wprost lub pośrednio, istniejącej narracji pamięciowej, proponując inne spojrzenie na miejsce i funkcję pamięci o Zagładzie w ukonstytuowaniu się izraelskiego społeczeństwa.

Pierwsza część artykułu stanowi ogólne omówienie pisarstwa drugiego pokolenia do końca XX wieku, kiedy twórczość ta skupiała się w szczególności na zaświadczaniu/opisywaniu osobistych wspomnień. W drugiej części szkicu przeanalizuję trzy powieści wydane w pierwszej dekadzie XXI wieku - Chamsin we-ciporim meszuga'ot Gawrieli Awigur-Rotem (2001), Hewzekim Michal Gowrin (2002) i Wered ha-Lewanon Lei Ejni (2009) ${ }^{11}$. Przyjrzę się stosowanemu w nich sposobowi podejmowania tematu Zagłady jako elementu rzeczywistości społecznej, kulturowej i politycznej. Ostatnia część poświęcona będzie książce Noama Chajota Gnewat ha-Szo'a szeli - reszimot szel ca'ir israeli $(2009)^{12}$. Utwór Chajota, przedstawiciela trzeciego pokolenia po Holokauście, wnosi do dyskusji na temat pamięci o Szoa kontekst militarny oraz wątek wykorzystywania jej przez Izraelskie Siły Zbrojne.

\section{Literatura drugiego pokolenia}

Nawa Semel, przedstawicielka drugiego pokolenia, w wykładzie wygłoszonym na Uniwersytecie Bar-Ilana (2003) tłumaczyła, że rolą pisarstwa literackiego o Zagładzie, jak każdej działalności twórczej, jest „wniesienie wartości dodanej, wykraczającej poza bezpośrednią wiedzę, czegoś, co nie będzie mówiło o tym, co znane, ale umożliwi inne, nowe spojrzenie na to, co zostało wyeksploatowane w codziennym dyskursie"13. Pojawiając się w połowie lat 80 . XX wieku, literatura

${ }^{11}$ G. Awigur-Rotem: Chamsin we-ciporim meszuga'ot. Tel Awiw 2009; L. Ejni: Wered ha-Lewanon. Tel Awiw 2009; M. Gowrin: Hewzekim. Tel Awiw 2002.

${ }^{12}$ N. Снајот: Gnewat ha-Szo'a szeli - reszimot szel ca'ir israeli. Tel Awiw 2009.

${ }^{13}$ N. Semel: Ktiwa tachat trauma. Tamcit dwarim sze-ne'emru be-jom ijun be-Uniwersitat Bar Ilan. Dostępne w Internecie: navasemel.com/index.php?page_id=164. Książka Nawy SemeL 
drugiego pokolenia po Zagładzie w Izraelu istotnie wprowadziła do dyskursu publicznego ten pierwiastek nowości, nie mówiąc „o tym, co znane”14. Umożliwiła nowe i różne od wcześniejszych spojrzenie na pamięć o Szoa oraz unaoczniła te treści, które zostały przez panujący dotąd i znany dyskurs wyparte - narrację ocalenia i przetrwania, historie zaczerpnięte $\mathrm{z}$ pamięci indywidualnej. Ten proces literacki wywarł znaczący wpływ na recepcję katastrofy, na rozumienie rzeczywistości, z którą musieli zmagać się ocalali i ci, którzy zginęli, na pamięć zbiorową, a w szczególności na zakwestionowanie wyrażenia „Zagłada i bohaterstwo" jako wyłącznego symbolu pamięci. Z perspektywy czasu można powiedzieć, że literatura ta odegrała istotną rolę dla zmian, jakim podlegała społeczna pamięć o Szoa, i dla procesu poszerzania granic izraelskiej tożsamości ${ }^{15}$.

Równolegle z opowiadaniem o indywidualnym doświadczeniu literatura drugiego pokolenia od samego początku podejmowała kwestie żydowsko-izraelskiej teraźniejszości i podawała w wątpliwość hegemoniczną narrację. Przedstawiciele tej generacji lokowali samych siebie w strukturach pamięci rodzinnej, nie zaś w ramach narodowych wyobrażeń, upatrując swoje pochodzenie w zgliszczach i obozach, nie zaś „w morzu”, jak pisał Mosze Szamir o swoim bracie Eliku na początku książki Bemo jadaw... ${ }^{16}$. Fabuły swych utworów umiejscawiali niemal wyłącznie w scenerii rodzinnej. Ważkie problemy narodowe, takie jak prawo do ziemi, zagrożenie ze strony Arabów czy konflikt z Palestyńczykami, na pozór nie były obecne w historii, którą opowiadali. Decyzja o opisywaniu wydarzeń Zagłady, zarówno w rozumieniu historycznym, jak i psychologicznym jako katastrofy rodzinnej (nie zaś narodowej), już na najbardziej podstawowym poziomie czyni z rodziny (a nie z narodu) prymarną przestrzeń projektowania zdarzeń1 ${ }^{17}$. To tam, zgodnie ze słowami Eleonory Lew, znajduje się "archeologia przynależności: tata, mama, brat, siostra, niepodzielna komórka, konstelacja pierwotna i założycielska"18.

Decyzja autorów drugiego pokolenia o wyłączeniu kwestii politycznych z głównego nurtu konstruowanej dyskusji prowadzi do celowej dekonstrukcji związków ustanawianych między Zagładą a realiami politycznymi przez dyskurs instytucjonalny. Jednym ze sposobów jej realizacji w tekście jest opis służby

Kowa zchuchit: kowec sipurim szel ha-dor ha-szeni (Tel Awiw 1985) była jednym z pierwszych głosów twórców drugiego pokolenia po Zagładzie („który nie mówił o tym, co ogólnie znane”).

${ }_{14}$ Tworzenie pamięciowych narracji przez potomków ocalałych zmieniło kody funkcjonujące w literaturze o Zagładzie, zarówno na poziomie poetyki, jak i pod względem poruszanych w niej tematów. Zob. I. Milner: Kir'ej awar. Tel Awiw 2003, s. 106-149; T. Kosz Zohar: Etika szel zikaron: kola szel mnemozina be-sifrut ha-dor ha-szeni. Tel Awiw 2009.

${ }^{15}$ Zob. D. BAR-On: Al. ha-acherim sze-be-tochenu: tmurot ba-zehut ha-israelit mi-nekudat re'ut psichologit chewratit. Beer Szewa 1993; D. LAOR: Ha-Szinujim be-dimujeha szel ha-Szo'a: he'arot al ha-hebet ha-sifruti. „Katedra: Le-Toldot Erec Israel we-jiszuwa” 1993, 69, s. 160-164.

${ }^{16}$ M. Szamir: Bemo jadaw: Pirkej Elik. Tel Awiw 1967.

${ }_{17}$ Por. I. Milner: Kir'ej awar...; T. Kosz Zohar: Etika szel zikaron...

${ }^{18}$ E. Lew: Sug mesujam szel jatmut. Tel Awiw 1989, s. 12. 
wojskowej postaci. Nie jest to jednak obraz, który przystawałby do wyobrażenia o armii obecnego w dyskursie publicznym, gdzie wojsko stanowi główny punkt spóźnionej narodowej fantazji o ocaleniu i zemście, symbolizuje naukę, jaką naród żydowski wyciągnął z Zagłady: uznanie konieczności zbudowania wojskowej siły, strzegącej suwerenności państwa ${ }^{19}$. Szoa jest tu postrzegana jako koronny dowód na to, że bez silnej ochrony Żydzi nie mają szans na przetrwanie. Zagrożenie arabskie utożsamiono $\mathrm{z}$ zagrożeniem nazistowskim, co pozwoliło sformułować wniosek, że aby do Zagłady nie doszło ponownie, Państwo Izrael musi zbudować silną armię oraz całkowitą i stałą przewagę militarną w regionie $^{20}$. Samo wojsko izraelskie stało się aktywnym agentem pamięci za sprawą wizyt dowódców w obozach zagłady w Polsce, a dziedzictwo Holokaustu jest ważną częścią programu szkoleniowego dla żołnierzy, przede wszystkim zaś dowódców ${ }^{21}$.

Służba wojskowa stanowi element życia wielu przedstawicieli drugiego pokolenia w prozie narracyjnej, jednak nie posiada ona w tym ujęciu wymiaru kompensacyjnego. Nie jest doświadczeniem heroicznym ani syjonistycznym, dzięki któremu bohaterowie identyfikowaliby się z instytucją wojska i wyrażali wiarę w słuszność politycznej oraz militarnej drogi, nie pozostało w niej też nic ze spóźnionej narodowej fantazji o ocaleniu i zemście. Sami przedstawiciele drugiego pokolenia opisywani są jako wciąż cierpiący z powodu nieustannego wpływu, jaki na ich życie wywiera zagładowa pamięć rodziców. Służba w armii nie jest lekiem ani na tragedię ocalałych rodziców, ani na trudne dzieciństwo ich potomków ${ }^{22}$.

Reprezentatywny przykład stanowi tu postać Asafa Lazara, bohatera powieści Beniego Barbasza My First Sony. Asaf jest oficerem bojowym o poglądach politycznych dalekich od narodowego konsensusu. Wspiera polityczną aktywność

19 Por. A. Ben-Amos, T. Hoffmann: Banu leszachrer et Majdanek: masot Cahal le-Polin we-gijus zichron ha-Szo'a. „Socjologia israelit” 2016, 12 (2), s. 331-354. Zob. też: T. Hoffmann: Tistaklu alejhem i tir'u otanu: talmidim u-mefakdej Cahal nifgaszim be-Polin. W: Ha-Szoa: sza'at chinuch..., s. 141-165.

${ }^{20}$ Por. I. Zertal: Ha-Uma we-ha-mawet, zikaron u-politika. Or Jehuda 2003; B. Kimerling: Militarizm ba-chewra ha-israelit. „Tarbut u-Wikoret” 1993, 4, s. 123-140.

${ }^{21}$ Por. A. Ben-Amos, T. Hoffmann: Banu leszachrer et Majdanek... Pomimo osiągnięcia konsensusu polityczne i militarne wykorzystywanie pamięci o Zagładzie poddano krytyce, zgodnie z którą ma ono legitymizować działania armii i wzmocnić poczucie słuszności obranej przez nią drogi. Zob. też: I. Zertal: Ha-Uma we-ha-mawet, zikaron u-politika...; A. RAZ-KraKotZKIN: Galut be-toch ribonut: la-bikoret szel „szlilat ha-galut” ba-tarbut ha-israelit. „Teoria u-Wikoret” 1994, 5, s. 113-132.

${ }^{22}$ Asaf Lazar, bohater powieści My First Sony (B. Barbasz: My First Sony. Tel Awiw 1994), Moja z powieści Iwer cwa'im (J. Buczan: Iwer cwa'im. Tel Awiw 1990), Arnon Grinberg z powieści Agadat ha-agamim ha-acuwim (M. LewI: Agatat ha-agamin ha-acuwim. Jeruszalajim 1989) i Gawriel Jederman z powieści Anatomia szel nekama (R. Keren: Anatomia szel nekama. Tel Awiw 1993) to jedynie kilka przykładów bohaterów - reprezentantów drugiego pokolenia, którzy odbywają służbę wojskową postrzeganą jako oczywisty element ich izraelskiej tożsamości. 
swojej żony Almy, działaczki lewicowej, nawet za cenę poważnego konfliktu z ojcem, narodowym prawicowcem, który postrzega Arabów jako kontynuatorów działań nazistowskich. Pomimo władzy i autorytetu mających wynikać z jego miejsca w wojskowej hierarchii Asaf nie znajduje w nich lekarstwa na głębokie zranienie wywołane zagładowymi wspomnieniami matki i innych ocalałych, które spisuje. Ostatecznie, opadłszy z sił, Asaf odbiera sobie życie.

Również sami ocalali, bezpośrednie ofiary tragedii, nie są w literaturze drugiego pokolenia przepełnieni żądzą zemsty. Hela, ocalała z Holokaustu matka Moi, bohatera powieści Jaakowa Buczana Iwer $c w a^{`}$ im, ostrzega przed niebezpieczeństwem drzemiącym w umacnianiu się i kumulowaniu sił, które traktowane są jako jedyna nauka wyciągnięta z Zagłady:

Żydzi wyhodowali tu potwora. Potężnego potwora, który wysysa z nas wszystko. I obwieszczają całemu światu [...], że nie będzie więcej Zagłady, że tutaj jest państwo żydowskie, że więcej nie pozwolą, a jeśli znów do tego dojdzie, cena będzie bardzo, bardzo wysoka - kula ziemska wybuchnie. [...] Taka siła, jaką ma izraelski naród w Państwie Izrael, w Erec Israel, taka siła przecież też musi się kiedyś rozpaść. [...] Ty, ja i wszyscy Żydzi musimy uważać ${ }^{23}$.

Siła przedstawiana przez syjonizm jako wartość i wizja, tutaj ukazana zostaje jako niszczycielska. W przeciwieństwie do głoszonej przez armię znanej frazy o przyjmowanej przez nią - zarówno realnej, jak i symbolicznej - roli ochrony przed „drugą Zagładą” oraz o ukojeniu i zemście, jakie oferuje ona ocalałym i ich rodzinom, siła została tu opisana jako zagrożenie.

Do tekstów wkradają się też niekiedy ślady po przemilczanej palestyńskiej przeszłości, z którą zmaga się drugie pokolenie. Dzieje się tak na przykład w powieści Eleonory Lew Sug mesujam szel jatmut, w całości poświęconej podróży $\mathrm{w}$ poszukiwaniu rodzinnych korzeni i tworzeniu świadectwa (wymazanego) życia przodków w przedwojennej Polsce ${ }^{24}$. Narratorka decyduje się opowiedzieć o nieoczekiwanym i wprowadzającym zamęt spotkaniu z pozostałościami po palestyńskim losie tutaj, w trakcie przechadzki po sadach w sobotni poranek: „[...] pagórek, drzewa eukaliptusa, żywopłot opuncji, sterty ociosanych kamieni, których nie da się z niczym pomylić" - wszystko to typowe ślady zniszczonej arabskiej wioski ${ }^{25}$. Jej towarzysz życia przypomina sobie, ,że w jego dzieciństwie były tam też arabskie groby. Ale zniknęły i dziś już ich nie ma" ${ }^{26}$. Uderza ich podobieństwo do gruzów żydowskiej przeszłości, które widzieli w Polsce: „»Miśnicz«, pomyśleliśmy oboje”27. Podobnie uderza ich myśl, że ta zburzona wioska to przemilczana historia, której zupełnie nie znają:

\footnotetext{
23 J. Buczan: Iwer cwa'im..., s. 51-52.

24 Por. E. Lew: Sug mesujam szel jatmut...

25 Tamże, s. 222.

26 Tamże.

27 Tamże.
} 
Nie znamy dokładnych okoliczności, dat [...], ani nawet nazwy wioski, która tu kiedyś była, ale oboje natychmiast wyobrażamy sobie ludzi, którzy żyją i oddychają [...], ludzi, o których pamięć stopniowo się zaciera na tym skrawku ziemi pośród sadów: to ich prawo własności, to samo uczucie bycia okradzionym, źródło ich bólu i nienawiści, za to oni i my będziemy zabijać i ginąć, oni zabijają nas, a my ich przez te wszystkie lata ${ }^{28}$.

Lew uznaje podobieństwo między wspomnieniami ukrytymi w stertach gruzów „tam” i „tutaj”, szczątkami świadczącymi o wymazanej przeszłości, pamięcią o przemilczanej krzywdzie. Jest wstrząśnięta „tym żałosnym współzawodnictwem pamięci i tragedii" i formułuje niemal niedozwolone pytanie o tutejszą palestyńską przeszłość oraz związki między dwiema pamięciami: „Ocalały z jednej tragedii żyje obok szczątków innej, co?”29. Świadomość ta budzi w niej przede wszystkim poczucie winy i dyskomfortu. Podobnie jak bohaterowie S. Izhara staje w obliczu ruin zburzonej wioski, uznaje niesprawiedliwość, która się dokonała, ból innego, któremu zagrabiono dom, i tak jak oni, z bólem i wahaniem, ostatecznie przyjmuje wyrok: „[...] życie jest nieuniknioną wojną” ${ }^{30}$. Dalej stwierdza:

Nie zamierzałam być kolejnym pokoleniem po Zagładzie lub reprezentantką Polaków, wypędzającą czy wykorzystującą Arabów, albo nie wiem co... [...] Chciałam tylko przejść się w sobotni poranek w ciepłym słońcu, nie odbierając nikomu prawa do jego słońca i jego soboty - ale czy to w ogóle możliwe? W jakim stopniu wolno mi pozwolić sobie na selektywne przyswajanie przeszłości ${ }^{31}$ ?

W niepokojący sposób głębokie poczucie winy narratorki w związku z wyrządzoną niesprawiedliwością i jej bezsilność wobec tego faktu pomagają jej odbudować swoją pozycję moralną i obraz siebie: „nie zamierzałam”. Paradoksalnie przyjęcie do wiadomości krzywdy pomaga jej wybrać milczenie i zgodzić się (choć nie bez niepokoju), że tragedia Zagłady legitymizuje niesprawiedliwość wyrządzoną (z braku wyboru) Arabom oraz jej przemilczenie.

Również w późniejszej powieści Alizy Olmert Prusa szel jam palestyńska przeszłość obecna jest i w krajobrazie, i, w sposób zagrażający, w świadomości głównej bohaterki ${ }^{32}$. Postać, którą autorka przedstawia jako osobę sprzeciwiającą

28 Tamże.

29 Tamże.

30 Tamże.

31 Tamże.

32 A. Olmert: Prusa szel jam. Lod 2001. Fabuła powieści obejmuje pierwsze lata istnienia państwa, gdy do Izraela przybywali uchodźcy ocalali z Zagłady, a wielu z nich zostało zakwaterowanych w pustych domach arabskich obywateli, którzy uciekli lub zostali wypędzeni. Bohaterowie powieści, Olek i Anuszka, para ocalałych wraz z małą córeczką, „otrzymali” mieszkanie 
się syjonistycznej wizji słowem i czynem, dostrzega to, co owa wizja usiłuje stłumić: arabską Jafę. Podczas codziennych spacerów z córką wybiera jako miejsce do odpoczynku ruiny meczetu Hassana Beka. Właśnie tam, na gruzach innej wypartej przeszłości, decyduje się opowiedzieć o tym, co przeszła ona sama o Zagładzie, w jej języku - po polsku. W mieszkaniu, w którym zakwaterowano jej rodzinę, bohaterka wciąż wyczuwa puls dawnego życia, jakie się tam toczyło. Pustkę przepełnia poczucie nieobecności prawdziwych właścicieli domu, a wytworny żyrandol, który po nich pozostał, ostatni ślad kwitnącego tam niegdyś życia, stanowi dla niej groźbę powrotu właściciela. W ścianach palestyńskiego mieszkania bohaterka prowadzi własną „rodzinną ścianę”. Przyczepia do niej zdjęcia pomordowanych krewnych, dając przestrzeń własnej pamięci, podczas gdy $\mathrm{w}$ górze unosi się duch pamięci palestyńskiej, a $\mathrm{z}$ wnętrza zwisającego $\mathrm{z}$ wysokiego sufitu ozdobnego żyrandola spogląda groźba powrotu tego, co politycznie zostało wyparte.

Wdzierająca się do świata przedstawionego fala przeszłości pozwala połączyć aktualne kwestie podnoszone przez literaturę hebrajską w początkach jej istnienia, czyli tragedię Żydów i wygnanie Arabów w trakcie wojny o niepodległość. Spostrzeżenie sformułowane przez bohatera opowiadania S. Izhara Hirbet Hiz'a: „[...] dwa tysiące lat wygnania i co tylko. Europa. Mordowanie Żydów. A teraz to my jesteśmy panami..." ${ }^{33}$, wciąż na nowo niepokoi bohaterów drugiego pokolenia. Jak twierdzi Rut Firer, konfrontowanie się z tego typu pytaniami powinno stanowić nieodłączny komponent nauczania o Zagładzie. Wszechobecność Holokaustu w rzeczywistości Izraela, od momentu jego powstania, zobowiązuje do nauczania o nim również w tym historycznym kontekście. Firer jest zdania, że moralne dylematy rodzące się podczas nauczania o Szoa, jak na przykład naturalne prawo do bezpieczeństwa i wolności oraz odpowiedzialność jednostki za postawę moralną państwa, powinny być poddawane dyskusji, również w aktualnym kontekście, w oderwaniu od stanowisk (i demagogii) partii prawicowych i lewicowych ${ }^{34}$.

\section{Literatura drugiego pokolenia - reakcja na izraelski stan wyjątkowy}

U progu XXI wieku w literaturze drugiego pokolenia można zauważyć intensyfikację bezpośrednich krytycznych odniesień do prowadzonych nieustannie

w odebranej właścicielom arabskiej posiadłości w Jafie i próbowali zbudować w nim swoje nowe życie.

${ }^{33}$ S. Izhar: Hirbet Hiz'a. W: TenżE: Arba'a sipurim. Tel Awiw 1964, s. 109.

${ }^{34}$ Por. R. Firer: Sochnim szel ha-lekach. Tel Awiw 1989. 
przez Izrael wojen i leżącego u ich podstaw konfliktu izraelsko-palestyńskiego, a także do związków (zwykle wypieranych z publicznego dyskursu) między żydowską traumą Zagłady a palestyńską traumą Nakby. Wojny, okupacja i bunt społeczności palestyńskiej są obecne $\mathrm{w}$ literaturze drugiego pokolenia przy jednoczesnym zacieśnieniu się relacji łączącej te doświadczenia z wciąż obecną pamięcią o Szoa. Chciałabym wskazać zatem trzy dzieła, których akcja każdorazowo została osadzona $\mathrm{w}$ realiach jednej $\mathrm{z}$ izraelskich wojen: powstania Palestyńczyków (intifady), pierwszej wojny w Zatoce Perskiej i wojny w Libanie. Każdy z tekstów opisuje stan wyjątkowy, politycznie definiowany jako działanie władz mające chronić podległych im obywateli przed zagrożeniem (klęską żywiołową, zamachem terrorystycznym, wojną). To w rękach rządzącego leży decyzja o czasowym zawieszeniu praw celem uporania się z zaistniałą katastrofą. Stan wyjątkowy daje mu szczególną władzę, choć jak twierdzi Adi Ofir, $\mathrm{z}$ jednej strony oferuje on środki do obrony i niesienia pomocy obywatelom, ale $\mathrm{z}$ drugiej - także do krzywdzenia i szkodzenia im ${ }^{35}$. Giorgio Agamben upatruje w stanie wyjątkowym zalążki nowoczesnego totalitaryzmu. Jak stwierdza, ogłoszenie stanu wyjątkowego jest ,jedną z fundamentalnych praktyk współczesnych reżimów, również tych określanych jako demokratyczne"36.

Stawianie czoła tragedii w sytuacji definiowanej jako stan wyjątkowy zwykle godzi na pewien czas (aż do ustania niebezpieczeństwa) w wolność publiczną i wynikające $z$ niej prawa. W Państwie Izrael stan wyjątkowy panuje od momentu, kiedy go ogłoszono, a Zagłada wprzęgnięta zostaje w mechanizm usprawiedliwiający jego nieustającą opresyjność ${ }^{37}$.

Obraz tej sytuacji ukazany został w trzech powieściach, na których chcę się skupić. W Chamsin we-ciporim meszuga'ot Gawrieli Awigur-Rotem bohaterka, Liwia, zmaga się $\mathrm{z}$ nieprzerwanie panującym $\mathrm{w}$ Izraelu stanem wyjątkowym oraz z wysoką ceną, jaką za niego płaci. Ramy powieści wyznacza wizyta Liwii w Izraelu po ponad dwudziestu pięciu latach nieobecności w celu odebrania odziedziczonego domu. Wizyta wydłuża się, a w jej trakcie w domu dzieciństwa

${ }^{35}$ Por. A. Ofir: Zman u-merchaw be-macaw ha-cherum. W: Li-fnim mi-szurat ha-din: he-charig u-macaw ha-cherum. Red. I. Szenhaw, Ch. Schmidt, Sz. Celniker. Jeruszalajim 2009, s. $55-68$.

${ }^{36}$ G. Agamben: Macaw ha-cherum. W: Li-fnim mi-szurat..., s. 134. Agamben pisze tu o procedurze prawnej, która obowiązywała w państwie nazistowskim, krótko po dojściu Hitlera do władzy - „poprawce dla obrony narodu i reżimu”.

${ }^{37}$ Ordynacja o Organizacji Władzy i Sądownictwa, uchwalona po ogłoszeniu niepodległości, dawała Tymczasowej Radzie Państwa prawo informowania o zaistnieniu stanu wyjątkowego i pozwalała wdrożyć wszelkie regulacje, na mocy których można było „zmienić każde prawo, czasowo je unieważnić lub narzucić na nie warunki, a także nałożyć podatki i inne opłaty obowiązkowe” (par. 9 Ordynacji o Organizacji Władzy i Sądownictwa, 1948). Cztery dni po uchwaleniu ordynacji istotnie wprowadzony został stan wyjątkowy, który nigdy się nie zakończył. Choć stan wyjątkowy powinien zostać odwołany automatycznie w ciągu roku od jego ogłoszenia, Kneset co kilka miesięcy przedłuża czas jego obowiązywania. 
otwierają się szuflady pełne listów, dzienników i rodzinnych sekretów z czasów Zagłady. Fabuła rozciąga się między dwoma planami czasowymi: teraźniejszością - realiami Izraela lat 90., w które wrzucona zostaje Liwia, i przeszłością: jej dzieciństwem i latami dojrzewania w Izraelu lat 50. i 60. XX wieku, w moszawie, którego większość dorosłych mieszkańców stanowią ocalali z Zagłady, a większość dzieci wychowywała się w założonych przez nich rodzinach.

Pamięć drugiego pokolenia po Holokauście zostaje w powieści zderzona $\mathrm{z}$ realiami Izraela około pięćdziesiąt lat po wojnie. Akcja rozgrywa się na tle nieprzemijającego konfliktu izraelsko-palestyńskiego: brutalnego sprzeciwu wobec ugody z Palestyńczykami i gróźb zamachu na premiera; intifady, ostrzeżeń, wszechobecnych aktów terroru, zamachów, usuwania zwłok zamordowanych; wojny w Libanie i jej licznych ofiar. Z perspektywy bohaterki stan wyjątkowy jest dla otoczenia rzeczą naturalną i normalną. Wojny i pochłaniające kolejne ofiary operacje wojskowe, nieustanna obawa rodziców o synów-żołnierzy, śmierć młodych żołnierzy w Libanie czy ciężko ranni podczas intifady to doświadczenia niemalże należące do codziennej rutyny. Kobieta odkrywa, że odkąd opuściła Izrael, nie zapanował tu spokój. Wojny jej dzieciństwa i lat młodzieńczych, takie jak wojna Jom Kipur czy wojna na wyczerpanie, zostały zastąpione przez nowe konflikty zbrojne, jak wojna w Libanie i intifada, a listy z nazwiskami poległych nadal się ukazują.

Liwia obserwuje życie toczące się w zalewie doniesień o „atakach nożowników"38. Złe, pełne grozy wiadomości napływają bez przerwy. Przebijają się $\mathrm{z}$ relacji radiowych, $\mathrm{z}$ telewizji i gazet, informują o tragediach, budzą przerażenie w rodzinach żołnierzy:

Radio w twoim pokoju podaje szczegóły z miejsca zdarzenia - siedmiu zabitych - dziesiątki ciężko rannych - zamach samobójczy czterdzieści dni po rzezi w Hebronie - syreny karetek [...] Śmierć A-ra-bom! Śmierć A-ra-bom! Krzyki w tle i płacz - i znów hałas, z którego przebijają się rytmiczne wołania: Rabin zdrajca! Rabin zdra - i przeciągły pisk, a potem już tylko głucha cisza [... $]^{39}$.

O bolesnych doniesieniach mówi się w każdym zakątku kraju, panuje poczucie, że każdy kolejny zamach jest tylko kwestią czasu i że może wydarzyć się wszędzie: „Tydzień temu w Afuli, dzisiaj w Chaderze, pojutrze uderzą w domu kultury i sportu [...], nie - następny zamach będzie w Jerozolimie [...] albo w centrum Tel Awiwu - w Miejskim Centrum Kultury, w centrum handlowym Dizengoff" ${ }^{\prime 40}$. Choć podstawowym celem stanu wyjątkowego jest uporanie się z zaburzoną sytuacją, w praktyce tylko nasila on niepokoje: „Spokoju tutaj nie ma i nie będzie. Urządzili nam Zagładę w Dzień Pamięci o Zagładzie [...]. Nie

\footnotetext{
38 G. Awigur-Rotem: Chamsin we-ciporim meszuga'ot..., s. 200.

39 Tamże, s. 246.

40 Tamże, s. 331.
} 
mam siły, nie mam siły, wierz mi, kupuję gazetę i czytam tylko dział sportowy to ziemia, która pożera swoich mieszkańców, tutaj" ${ }^{\text {11 }}$.

Izraelska rzeczywistość, którą Liwia zastaje po wieloletniej nieobecności, wydaje jej się obłąkańcza, a państwo działa w jej odczuciu jak państwo policyjne. Kobieta nie zostaje wprawdzie ukazana jako osoba o wysokiej świadomości politycznej, jednak rozumie znaczenie stanu wyjątkowego i wie, jak wyglądałoby jej życie, gdyby została w Izraelu: byłaby wdową („wyszłabym za Elchanana i owdowiała w wieku dwudziestu trzech lat”) lub osieroconą matką („wyszłabym za Szlomiego [...], mielibyśmy dwóch synów i córkę, jeden z synów zginąłby na którejś z wojen") ${ }^{42}$.

W centrum powieści Michal Gowrin Hewzekim stoi kwestia konfliktu izraelsko-palestyńskiego: okupacja, wojny i szansa na pokój. Fabuła obejmuje różne wymiary polityczności: zaangażowanie bohaterki, Ilany, członkini radykalnego ruchu lewicowego, czynnej przeciwniczki izraelskiej polityki okupacyjnej i bojowniczki o prawa palestyńskiej mniejszości w Izraelu; jej zobowiązanie do pokoju; plan zbudowania przy współudziale Palestyńczyków pomnika Pokoju w Jerozolimie. Miejsce pamięci planowane przez Ilanę ma mieć formę sukki - szczególnej drogi upamiętnienia. Sukka jest miejscem, w którym żyje się i mieszka, a nie takim, które wyłącznie się ogląda. Ilana, jako inicjatorka budowy sukki mającej stanowić przestrzeń pamięci, tłumaczy swojemu palestyńskiemu współpracownikowi: „Rozumiesz [...], porzucić noże [...], dać sobie spokój tam, mieszkając w wiosce pełnej sukkot" ${ }^{\prime 33}$.

Również tutaj literacką rzeczywistość określają brutalna okupacja, palestyńskie ataki terrorystyczne na społeczeństwo obywatelskie, okres nalotów rakietowych na miasta i egzystencjalny lęk przed bronią chemiczną podczas pierwszej wojny w Zatoce Perskiej. Świadomość bohaterki, przepełniona myślami i wspomnieniami o poprzednich wojnach, dopełnia obraz stanu wyjątkowego ogarniającego Państwo Izrael. Ilana, przedstawicielka drugiego pokolenia, córka ocalałej, która sama wyszła za ocaleńca, stara się kierować swoim życiem zgodnie $\mathrm{z}$ wiarą w pokój, pomimo sprzeciwu ze strony męża. „Jaki sens mają te wszystkie twoje pomniki? Przecież dla tego konfliktu nie ma rozwiązania [...]. To nie jest problem terytorialny, to walka o samo istnienie. Muzułmański świat was tam nie przyjmie" ${ }^{\text {"44. }}$. Według niego niebezpieczeństwo zagłady jest realne, tylko „czeka, żeby podnieść głowę i okazać Żydom nienawiść na każdy możliwy sposób, [...] wszystko skończy się zagładą Izraela, a i wtedy nikt się nie ruszy, tak jak poprzednio $[\ldots]^{345}$.

\footnotetext{
${ }^{41}$ Tamże, s. 246.

42 Tamże, s. 325.

${ }^{43}$ M. Gowrin: Hewzekim..., s. 75.

${ }^{44}$ Tamże, s. 113.

${ }^{45}$ Tamże.
} 
W podobnym tonie wypowiada się Said, współpracujący w projekcie $\mathrm{Pa}-$ lestyńczyk, w którym Ilana beznadziejnie się zakochuje. Ten z kolei rezygnuje ze wspólnego projektu przygotowywanego przez bohaterkę, porzuca ją i wraca, podobnie jak jej mąż, do swojej narodowej tragedii, Nakby, i do kwestii prawa powrotu. Dwie narracje, syjonistyczna i palestyńska, trwale wiążą się z poczuciem krzywdy i tragedią, która się wydarzyła, i każda z nich wyraża chęć zemsty. Obydwaj mężczyźni delegitymizują drogę obraną przez bohaterkę, zakładającą rezygnację z pozycji ofiary, roszczeń do ziemi i do tragedii.

Gowrin proponuje dramatyczną przemianę świadomościową, na którą wskazuje tytuł książki: „rozbłyski”. Dekonstruuje ona ideę ustrukturyzowanej oraz stabilnej narracji i sugeruje, aby porzucić wszystkie jej wersje, zarówno lewicowe, jak i prawicowe, po stronie żydowskiej i po stronie arabskiej, i pójść naprzód, „poza symetrię nienawiści, symetrię uznawania się nawzajem za ofiary albo poczucia winy [...] Jestem na etapie otwierania nowej rzeczywistości i poniekąd rozluźniania więzi z tym nasiąkniętym krwią miejscem"46. Wszystko to wynika z założenia, że porzucenie „konstytutywnej narracji” pozwoli wybaczyć doznane krzywdy.

Podobnie jak w dwóch poprzednich powieściach również w Wered ha-Lewanon Lei Ejni akcja rozgrywa się w trakcie wojny, a rzeczywistość widziana jest oczami bohaterki, Lei/Wered, z zewnątrz do centrum. W przeciwieństwie do protagonistek dwóch wcześniejszych utworów urodziła się ona i żyje w Izraelu, choć podobnie jak one także zajmuje tam pozycję obcej, innej. Jej odmienność wiąże się z miejscem w izraelskiej hierarchii społecznej - kulturowym, etnicznym i ekonomicznym marginesem. Odmienność ta związana jest też z przestrzenią „pomiędzy”, którą bohaterka sama sobie stworzyła, nienależącą ani do centrum, ani do marginesu, gdzie się wychowała. W ramach tej przestrzeni kształtuje ona swoje krytyczne spojrzenie i głos oraz formułuje jasne stanowisko polityczne ${ }^{47}$.

Z tego miejsca kobieta wyraża stanowczy sprzeciw wobec wojen i umożliwiającej je retoryki, skrajnego militaryzmu, w którym młodzi ludzie tak naturalnie i dobrowolnie stają się żołnierzami i podążają jak ślepi „z tymi swoimi wojnami [...], idą na pewną śmierć, całą drogę, od dzieciństwa aż po Liban [...]"48, gotowi „Zaprzedać duszę nienasyconym żołądkom polityków”49. Lei/Wered krytykuje narrację dyktującą państwowy porządek wojen: „[...] cali jesteśmy pokryci wojną, z niej się wzięliśmy i nie umiemy inaczej. Wojna jest zawsze i nawet jeśli któregoś

46 Tamże, s. 212.

47 O przestrzeni „pomiędzy” jako przestrzeni postkolonialnej, w której obywatel nie identyfikuje się ani z okupantem, ani z miejscową narracją, miejscu umożliwiającym zajęcie wyjątkowego stanowiska, zob. J. Szenhaw, Ch. Chaber: Ha-Mabat ha-postkoloniali. „Teoria u-Wikoret” 2000, nr 20, s. 9-22.

48 L. Ejni: Wered ha-Lewanon..., s. 344.

49 Tamże, s. 19-20. 
pięknego dnia się kończy, to kończy się po to, żeby ustąpić miejsca następnej”"50. Potępia kłamliwość tej retoryki, zarzucając jej ukrywanie historycznych faktów, w tym takich jak potworności konfliktów zbrojnych i prawdziwe powody, dla których nieustannie się je wszczyna. W ten sposób ukryto prawdziwą motywację inwazji na Liban za twierdzeniem o jej „nieuchronności” i za nadanym jej kryptonimem szeleg $^{51}$ : taka wybielająca krew semantyka przykrywa zarazem prawdziwą potworność wojny. Wzrok bohaterki z opóźnieniem rejestruje wydarzenia z szybkiej trasy, na której wypadki rozgrywają się z dala od pola widzenia: ranni z Libanu wynoszeni $z$ helikopterów lądujących na dachach szpitali i natychmiast przenoszeni na oddziały ratunkowe, patologii lub prosto na cmentarze. Koszmar ten rozgrywa się z dala od żywych, próbujących żyć, jak gdyby wojny nie było. Tętniący życiem Tel Awiw zostaje w powieści przedstawiony jako metafora ślepoty, tego, że "ten naród, chory, poraniony, konający, ten naród nigdy nie dochodzi do siebie" ${ }^{52}$. Możliwość wyzwolenia od tragedii Zagłady oferowana przez dyskurs syjonistyczny nie znajduje potwierdzenia. Naród pozostał chory, a jego rany bardzo głębokie: „[...] badania, prześwietlenia i analiza próbek wskazują na poważne pęknięcia czaszki, ropne zapalenia kory mózgowej, oparzenia i rany kłute ciała i duszy, metalowe odłamki, które pozostaną na zawsze, całe i zdrowe, w nerkach, w płucach i w pamięci”"53.

Przedstawiony przez bohaterkę Ejni obraz rzeczywistości wydobywa na plan pierwszy obrażenia „tkanek miękkich” i rany pamięci, które nigdy się nie goją. Dodatkowo nie sprzyja temu przeobrażenie ocalałych i ich potomków w żołnierzy. Jako córka ocalałego z Zagłady, „absolwenta” czterech obozów koncentracyjnych, Lea/Wered dobrze zna $\mathrm{z}$ domu rodzinnego uczucie ciągłej obecności pamięci o Szoa. Ocalały ojciec przedstawiony jest jako człowiek brutalny, zarówno fizycznie, jak i werbalnie, który zarazem wykorzystuje swoją pozycję ofiary jako „środek do osiągnięcia wszystkiego. Wszystkiego, również przyciągnięcia uwagi. I na pewno do osiągnięcia zaspokojenia. Wszystkie sposoby były dozwolone" ${ }^{\text {. }}$. Ten sposób działania autorka odnajduje też na poziomie państwowym. Także tutaj tożsamość ofiary budzi pragnienie siły, jest stosowana do osiągania „wszystkiego" oraz utrwala mit ofiary, której egzystencja w dalszym ciągu jest zagrożona, ofiary, która wciąż na nowo domaga się uznania swojej krzywdy oraz prawa do stosowania siły. Utrwalająca tożsamość ofiary pamięć Zagłady legitymizuje państwo wojownicze i agresywne, które „wciąż rozpoczyna swoją drogę przez świat, niczym dziecko Goliata"s5.

50 Tamże, s. 538.

${ }^{51}$ Hebr. „śnieg”, a także skrót od שלום הגליל, „szalom ha-Galil”, nazwy operacji, w ramach której rozgrywały się walki między Izraelem a Syrią na terytorium Libanu podczas pierwszej wojny libańskiej w 1982 r. [przyp. tłum.].

52 L. Ejni: Wered ha-Lewanon..., s. 98.

53 Tamże.

54 Tamże, s. 229.

55 Tamże, s. 101. 
Bohaterka Ejni rozplątuje ofiarniczy węzeł utrzymujący oficjalny dyskurs o Szoa, łączący pamięć o niej z działaniami politycznymi, i w związku z tym może podjąć refleksję nad słusznością pozycji „świętych krów”, takich jak: prawo do ziemi przodków, prawo powrotu, status Jerozolimy jako wiecznej stolicy Izraela czy przemilczanie Nakby. Lea/Wered rozpoznaje związek między traumą Szoa i palestyńską tragedią. Przyjmuje pozycję skrajną, odrzucającą syjonistyczną argumentację: „Kto miałby uwierzyć, że po dwóch tysiącach lat życia $\mathrm{w}$ diasporze można wrócić z miast takich jak Saloniki, Wilno i Auschwitz ${ }^{56}$, i złączyć się biblijnymi więzami z tą największą z legend, podczas gdy ziemie, o których mówi, są już od wieków zakorzenione w historii innego narodu?" 57 . $Z$ jej punktu widzenia "powrót do Syjonu” to proces pełen przemocy, powielający krzywdę i oddalający szansę uleczenia. „Po Zagładzie powinniście byli zostać [...], siedzieć w jednym miejscu i się nie ruszać, dopóki czegoś z wami nie zrobią i [...] zabiorą $\mathrm{w}$ miejsce, gdzie nie odkryjecie nagle innych, gdzie historia nie będzie zwalczała innej historii [...] gdzie będziecie mogli po trochu wyzdrowieć i żyć, gdzie nie spadnie na was wstyd"58.

Trzy zaprezentowane powieści podejmują - na różne sposoby - temat związku między pamięcią Szoa a panującym w Izraelu stanem wyjątkowym, wraz $\mathrm{z}$ mechanizmem jego usprawiedliwiania, oraz przedstawiają narodowe realia stale powracających traum. Dominick LaCapra opisuje taką rzeczywistość jako stan kolektywnej posttraumy, tj. niekontrolowane nawroty posttraumatycznych symptomów $\mathrm{w}^{59}$. Przepracowanie traumy, a także w pewnym stopniu krytyczna refleksja nad nią, pozwala powstrzymać kompulsywne posttraumatyczne nawroty. Z kolei nieprzepracowana trauma może uwięzić społeczeństwo wewnątrz systemu nieświadomych, szkodliwych zachowań i władzy, od których trudno się uwolnić. Zgodnie $\mathrm{z}$ koncepcją LaCapry opisywany w tych powieściach izraelski stan wyjątkowy stanowi przykład niekontrolowanej posttraumy. Powtarzalność wojen, powtarzalność mechanizmu „krzywda za krzywdę, zaprzeczenie za zaprzeczenie" ${ }^{" 60}$, jak określa to bohaterka Ejni, unaocznia nieprzepracowaną zbiorową traumę. Wskazuje ona na mechanizm powielania agresji wewnątrz izraelskiego społeczeństwa i oddalającą się perspektywę uleczenia: „Przywódcy wojskowi, którzy powołali do życia dowódców wojskowych, działaczy wojskowych, rzeczników wojskowych, gazety wojskowe, komentatorów wojskowych,

${ }^{56}$ Wymienne stosowanie nazwy obozu: Auschwitz, i nazwy miasta: Oświęcim, jest błędem popełnianym niekiedy przez izraelskich autorów i autorki [przyp. tłum.].

${ }^{57}$ L. EJNI: Wered ha-Lewanon..., s. 347.

58 Tamże, s. 472.

59 D. LaCapra: Pisanie historii, pisanie traumy. Przeł. A. Rejniak-Majewska. W: Pamięć Shoah. Kulturowe reprezentacje i praktyki upamiętnienia. Red. T. Majewski, A. ZeIdLer-JANISZEWSKA. Łódź 2009, s. 499-528.

${ }^{60}$ L. EjnI: Wered ha-Lewanon..., s. 415. 
wojskowych posłów do Knesetu, wojskowych premierów - oni, którzy powołali do życia społeczeństwo nieobywatelskie, boją się rozumieć” ${ }^{\prime \prime 1}$.

W takiej rzeczywistości każda inicjatywa ze strony bohaterów, aby przepracować traumę na poziomie publicznym, jest skazana na klęskę. Dla Liwii $\mathrm{w}$ powieści Chamsin we-ciporim meszuga'ot wizyta w Izraelu stanowi okazję do poznania sekretów z przeszłości i otwarcia rodzinnych ran, wypartych i przemilczanych. Bohaterce udaje się wprawdzie odkryć sekrety, spotkać się z matką, która wcześniej zniknęła, i „zamknąć koło” własnej historii. Jednakże w brutalnej rzeczywistości wojny o grunt pod zabudowę (grunt w kontekście tego konfliktu jest pojęciem znaczącym), trauma, którą reprezentuje jej rodzinny dom, zbudowany na kłamstwach i sekretach, nie zostaje przepracowana. Scena kończąca powieść jest wizją trudnego powrotu do stanu traumy: przyczepiony do zamkniętych drzwi oficjalny nakaz wyburzenia, zaparkowany na podwórku ciężki sprzęt gotowy do niszczenia, odcięty dopływ wody.

W powieści Gowrin wydaje się, że możliwość przepracowania traumy w realiach izraelsko-palestyńskich jest utopią. Proponowany przez Ilanę inny sposób myślenia o sytuacji, oparty na wzajemnym uznaniu traumy innego, nie jest możliwy. Także Gowrin decyduje się zakończyć swoją powieść w atmosferze dramatu i nieszczęścia: Ilana, która opuściła Izrael, ginie w wypadku drogowym, a wraz z nią płód, który nosi w łonie. Jego tożsamość nie jest jasna: Palestyńczyk czy Żyd?

Lea/Wered uparcie sprzeciwia się żądaniom ojca, by spisała jego zagładowe wspomnienia, którymi się z nią dzieli. Wygląda na to, że właśnie jej krytyczne spojrzenie na traumę stanowi rodzaj przepracowania - to właśnie przez jego pryzmat bohaterka interpretuje rzeczywistość i dlatego jest zdolna uporać się $\mathrm{z}$ osobistą krzywdą. A jednak również w tym przypadku powieść kończy się w tonie rozpaczy: „Wojna nas przysłania, ta wojna w szczególności. Od ponad roku do ciebie przychodzę i wciąż nie widać końca"62.

$\mathrm{W}$ prezentowanych tekstach pamięć o Zagładzie wpisana została w aktualną rzeczywistość, istniejącą i znaną. Z jednej strony można w nich wyróżnić postawy niezwykle krytyczne wobec polityki kontroli, zwłaszcza w dziedzinie bezpieczeństwa, ale $\mathrm{z}$ drugiej udaje im się uniknąć politycznej pułapki podziału na "prawicę" i „lewicę". W ramach edukacji o Zagładzie literatura tego typu pozwala osadzić refleksję w codziennej rzeczywistości i odpowiednich dyskusjach na temat Szoa, takich jak egzystencjalny lęk przed „kolejną Zagładą” czy palestyńskie zagrożenie.

Powieści te umożliwiają też podjęcie kwestii (zwykle przemilczanej) związków między traumami obydwu narodów. Nie przyjmuje to jednak ani charakteru oskarżenia, ani apologetyki, a otwiera dyskusję uświadamiającą istnienie

\footnotetext{
61 Tamże, s. 174.

62 Tamże, s. 541.
} 
tego problemu i pozwala na rozmowę o nim, bez konieczności formułowania ostatecznych konkluzji.

\section{Literatura drugiego (i trzeciego) pokolenia jako punkt wyjścia debaty politycznej}

Książka Noama Chajota Gnewat ha-Szoa szeli - reszimot szel ca'ir israeli dodatkowo nasila literacki proces, któremu, jak wskazałam, podlegały poprzednie powieści, przez to, że autor określa ją jako autobiografię, czyli autentyczny zapis zdarzeń. Chajot opisuje drogę, jaką przebył od pozycji centralnej, soli Ziemi Izraela, ruchu osadnictwa pracującego, Doliny Jezreel, pewnego „słuszności obranej drogi”, aż do pozycji, z której zaczął ją podawać w wątpliwość, a nawet formułować wobec niej oskarżenia ${ }^{63}$.

W ujęciu generacyjnym autor należy do trzeciego pokolenia po Zagładzie, jednakże jego związek z nią ma charakter nie biologiczny, a kultu row y. Chajot opisuje proces edukacji, który ukształtował jego izraelską tożsamość opartą na gotowości wykonywania poleceń i moralnej pewności. Centralną rolę w tym procesie odgrywała edukacja dotycząca Szoa, od obchodów Dni Pamięci w szkole aż po pielgrzymkę do Auschwitz. Służba wojskowa stanowiła zaś oczywistą część wyciągania wniosków z Zagłady. Środek ciężkości w tekście Chajota wyznacza wątek kradziė̇y Zagłady, konstytutywny moment, w którym na oczach bohatera rozpada się jego wyobrażenie o sobie jako postępującym moralnie i słusznie, zbudowane na podstawie dziedzictwa Szoa i wyciągniętych z niej wniosków. Pęknięcia wiary w słuszność obranej drogi stały się zauważalne, gdy protagonista rozpoczął służbę wojskową na terytoriach okupowanych, w momencie gdy retoryka i rzeczywistość przestały się ze sobą zgadzać, kiedy związek między pamięcią Holokaustu, na której bohater się wychował, właściwą perspektywie ofiar a prawem gromadzenia i stosowania siły zaczął budzić w nim niepokój oraz pytania natury etycznej.

Opisywana w powieści świadomościowa przemiana zostaje w pełni sformułowana w scenie, w której uzbrojony (i pewien słuszności swojego postępowania) żołnierz napotyka przerażony wzrok palestyńskiej dziewczynki. W tym momencie żołnierzowi wojsk okupujących przypomina się symbol znany z kontekstu Szoa - zdjęcie chłopczyka z warszawskiego getta naprzeciw nazistowskich żołdaków. Kradzież Zagłady jest kradzieżą moralnego zaplecza okupacji i prawa

${ }^{63}$ Chajot był jednym z założycieli organizacji Szowrim Sztika, zajmującej się zbieraniem świadectw o zbrodniach izraelskich żołnierzy służących na terenie Hebronu w trakcie drugiej intifady. 
do stosowania siły, wraz z nią zburzeniu ulega struktura wartości i aksjomatów, i zmienia się całe równanie: jako uzbrojony żołnierz Chajot spogląda na swoją postać tak, jak odbija się ona w oczach zamarłej ze strachu palestyńskiej dziewczynki. Jego figura przechodzi z pozycji ofiary na pozycję oprawcy, z pozycji bohatera na pozycję agresora, z pozycji moralnego wojownika na pozycję żołdaka.

$\mathrm{Z}$ perspektywy Chajota wydarzenie to unieważnia jego dotychczasową wizję świata, zbudowaną na jego własnej Szoa. Dychotomiczny podział na dobrych (nas) i złych (Arabów) ulega rozmyciu, świadomość historyczna traci stabilność. „Nie mamy pojęcia, co stało się tu wczoraj, dokładnie tu, w naszym Ejn Jezreel" ${ }^{\prime \prime}$. Nasuwają się kolejne pytania o to, co dotąd pozostawało przemilczane: „Gdzie zniknęła ta wioska [Zar'ajn, na której terenie utworzono Kfar Jezreel], gdzie zniknęli mieszkający tu ludzie i zwierzęta? Co stało się z polami i sadami? Nie pytałem ani nikt mi nie opowiadał"65. Wątpliwości te pozwalają wyzwolić inne wspomnienia: „[...] pamięć mężczyzn, kobiet i dzieci, którzy tu żyli, [...] którym z dnia na dzień odebrano wszystko, którzy wyszli z domów i poszli na południe, w kierunku drogi u stóp wzgórz Gilboa, w stronę Dżeninu. Ich dzieci i wnuki spotkałem twarzą w twarz w obozach dla uchodźców, tam, gdzie wysłał mnie Saul. Nie król Saul, tylko generał Saul”66.

Podczas tego spotkania dokonuje się okrężny ruch, uderzający w młodych żołnierzy i obciążający ich traumą, podobnie jak całe izraelskie społeczeństwo. Chajot powtarza tu to, co w swojej powieści mówiła Lea Ejni o związku między traumą dwóch narodów i moralnymi dylematami, które ta wywołuje. Jak wyraził to Chajot $\mathrm{w}$ wywiadzie prasowym, „powodzenie okupacji oparte jest w znacznym stopniu na naszej zdolności pozostania na pozycji ofiary. Fakt, że wciąż przedstawiamy siebie, zarówno przed samymi sobą, jak i przed resztą świata, jako ofiary, pozwala nam od ponad czterdziestu lat wyrządzać zło innym"67.

Rozpad, „kradzież Szoa”, umożliwia poprawę i powstanie nowych znaczeń: „[...] przynależność się rozmywa, duma nie istnieje, wiara słabnie, żal się nasila, rodzi się przebaczenie" ${ }^{\prime 68}$. Zdanie to ustawia cały utwór w roli fundamentu dla dyskusji o możliwościach uleczenia traumy Zagłady, nie tylko u ocalałych, których liczba stale się zmniejsza, ale przede wszystkim u kolejnych pokoleń, dla których pamięć o Holokauście jest integralną częścią izraelskiej rzeczywistości.

Literatura o Zagładzie, tworzona dawniej i obecnie przez ocalałych, stała się oczywistą częścią programów edukacyjnych na ten temat - będąc autentycznym źródłem świadectw o tym, co się wydarzyło, a zarazem, jako korpus tekstów literackich, umożliwiając wgląd $\mathrm{w}$ tę dojmującą ranę. Proza drugiego (i trzeciego) pokolenia stanowi jej kontynuację, poszerzając odniesienia o konkretną

\footnotetext{
64 N. Сналот: Gnewat ha-Szo'a szeli..., s. 146.

65 Tamże, s. 144.

66 Tamże, s. 147.

67 https://www.haaretz.co.il/misc/1.1190587 [data dostępu: 15.02.2017].

68 N. Снајот: Gnewat ha-Szo'a szeli..., s. 63.
} 
perspektywę, adekwatną do teraźniejszości. Lektura omawianych tutaj i innych dzieł umożliwia rozpoczęcie dyskusji o dylematach i problemach związanych z pamiętaniem o Zagładzie dziś, w izraelskim społeczeństwie tu i teraz, w cieniu tragedii, która nieustannie nakłada na nas, Izraelczyków, moralne zobowiązanie do uniknięcia jej powtórzenia, w jakikolwiek sposób.

Tłumaczenie Jagoda Budzik

Talila Kosz Zohar - wykładowczyni Seminar ha-Kibucim w Tel Awiwie. Autorka między innymi monografii Etika szel zikaron. Kola szel Mnemozina we-siporet ha-dor ha-szeni la-Szoa („Etyka pamięci. Głos Mnemozyny i proza drugiego pokolenia po Zagładzie”. Tel Awiw 2009). Prowadzi międzyobszarowe badania dotyczące choreografii i ruchu, literatury oraz kultury. 